\title{
PENERAPAN ASAS PROPORSIONALITAS BAGI HAKIM DALAM MENGADILI SENGKETA KONTRAK
}

\author{
Oleh \\ Teguh Harissa \\ Pengadilan Negeri Madiun \\ rizalkapuk@yahoo.com
}

\begin{abstract}
In fact the appropriateness of the contract substance is the dismissibility of the parties ' wishes in a contractual relationship, which is based on agreement, proficiency, ability and compliance with statutory regulations. However, the appropriation and exegesis of the existence of a new problem, there is a double understanding, ambiguity to lead to the misinterpretation of the wishes of the contractual parties, which can cause The Parties ' rights and obligations. For this it is important to do a search of the red thread of a contract, which is expected to find the identity of a contract when disputed by the parties. In this case the principle of proportionality can be used as a parameter for judges in each level of justice in finding a win solution in the matter of the commercial contract he handled. This is because the proportionality measure of the exchange of rights and contractual obligations is always based on equitability, freedom, distributionproportionate that is not independent of the principle of accuracy, feasibility and Fit. All of which can be used as a red thread of the true meaning of a contractual relationship, which in fact does not have to be centered on the proportion of the distribution of rights and obligations mathematically, but more than that through The basic search of proportionality by the magistrate of the judge, then any contractual matters handled will be resolved worthily and appropriately (fair and reasonableness) in order to achieve a win-win solution among the parties in dispute.
\end{abstract}

Keywords: Contract, Proportionality Principle and Dispute Settlement

\begin{abstract}
Abstrak
Pada hakikatnya pemaknaan substansi kontrak adalah pengejewantahan keinginan para pihak dalam suatu hubungan kontraktual, yang berdasarkan pada kesepakatan, kecakapan, kebolehan dan kesesuaian dengan peraturan perundang-undangan. Akan tetapi pemaknaan dan pengejewantahan tersebut ada kalanyan menimbulkan persoalan yang baru, adanya pemahaman ganda, ambiguitas hingga berujung pada kesalahan penafsiran keinginan para pihak kontraktual tersebut, yang mana hal ini dapat menimbulkan tidak terpenuhinya hak dan kewajiban para pihak. Untuk itu penting dilakukan suatu penelusuran benang merah dari suatu kontrak, yang diharapkan dapat menemukan jati diri suatu kontrak apabila dipersengketakan oleh para pihak. Dalam hal ini asas proporsionalitas dapat dijadikan parameter bagi hakim di dalam setiap tingkat peradilan dalam mencari win win solution dalam perkara kontrak komersial yang ditanganinya. Hal ini dikarenakan ukuran proporsionalitas terhadap pertukaran hak dan kewajiban kontraktual selalu didasarkan pada nilai-nilai kesetaraan (equitability), kebebasan, distribusi- proporsional yang tidak terlepas dari asas kecermatan, kelayakan dan kepatutan. Yang mana kesemua itu dapat dijadikan sebagai benang merah penelurusan makna sesungguhnya dari hubungan kontraktual, yang pada hakikatnya tidak menitik beratkan pada proporsi pembagian hak dan kewajiban secara matematis belaka, namun lebih dari itu melalui penelusuran asas proporsionalitas oleh majelsi hakim, maka setiap perkara kontraktual yang ditangani akan terselesaikan secara layak dan patut (fair and reasonableness) demi mencapai win-win solution diantara para pihak yang bersengketa.
\end{abstract}

Kata Kunci: kontrak, asas proporsionalitas dan penyelesaian sengketa. 


\section{PENDAHULUAN}

Fondasi atau landasan utama dari suatu hubungan kontraktual adalah keadilan, yang mana pada akhirnya keadilan tersebut akan membawa pada suatu kondisi yang merepresentasikan keadilan dan equity dalam suatu hubungan kontraktual. Dalam perkembangannya Mahkamah Agung menolak setiap intervensi hakim terhadap kontrak yang telah disepakati para pihak. Hal ini didasarkan pada asas kebebasan berkontrak dan asas pacta sunt servanda yang mengikat kedua belah pihak. Pandangan Mahkamah Agung ini terekam dalam yurisprudensi Mahkamah Agung dalam perkara Ida Ayu Suryani melawan I Nyoman Sudirja, hal ini sebagaimana yang tertuang dalam Putusan Mahkamah Agung R.I. No. 289 K/Sip/1972, tanggal 22 Juli 1972. Hal ini disebabkan karena pada dasarnya sengketa kontrak terjadi karena para pihak tidak lagi dapat menemukan solusi bersama untuk menyelesaikan perbedaan yang muncul pada tahap pelaksanaan kontrak. Meskipun kontrak berlaku mengikat laksana undangundang, ketika terjadi sengketa, pelaksanaan kontrak menjadi tidak jelas. Masingmasing pihak tidak lagi secara sukarela melaksanakan prestasi yang telah diperjanjikan.

Berdasarkan putusan Putusan Mahkamah Agung R.I. No. 289 K/Sip/1972 tersebut terlihat Mahkamah Agung konsisten dengan yurisprudensi yang ada, yaitu hanya mendasarkan kontrak pada asas kebebasan berkontrak dan asas pacta sunt servanda semata. Mahkamah Agung tidak berusaha mengintervensi apa yang telah disepakati oleh para pihak, meskipun realitasnya bertentangan dengan asas kepatutan dan nilai-nilai hukum yang hidup dalam masyarakat. ${ }^{1}$ Hal ini juga tercermin dalam perkara antara Zainal Abidin melawan A.M. Mohamad Zainuddin dkk, yang telah diputus dalam Putusan Mahkamah Agung R.I. No. 1253 K/Sip/1973, tanggal 14 Oktober 1976. Dalam putusan tersebut Mahkamah Agung sependapat dengan pertimbangan hukum Pengadilan Negeri Lhokseumawe dan Pengadilan Tinggi Banda Aceh yang menganggap klausul bunga 20\% sebulan yang disepakati dalam kontrak bertentangan dengan nilai-nilai keadilan dan perikemanusiaan. ${ }^{2}$ Mahkamah Agung terlihat mulai melakukan intervensi terhadap kontrak yang dianggapnya tidak adil dan bertentangan dengan nilai-nilai yang hidup di masyarakat. 


\footnotetext{
${ }^{1}$ Putusan Mahkamah Agung R.I. No. 289 K/Sip/1972.

${ }^{2}$ Putusan Mahkamah Agung R.I. No. 1253 K/Sip/1973
}

Berdasarkan Putusan Mahkamah Agung R.I. No. 1253 K/Sip/1973

Mahkamah Agung berpendapat bahwa asas kebebasan berkontrak tidak bersifat mutlak, yang berarti dalam keadaan tertentu, hakim berwenang melakukan penafsiran hukum, oleh sebab itu sekalipun pada dasarnya hakim diberikan kewenangan oleh undang-undang untuk mengadili dan memutus setiap sengketa yang dihadapkan kepadanya, termasuk sengketa kontrak. Namun demikian, meskipun hakim memiliki kewenangan untuk mengadili dan memutus sengketa kontrak, tentunya kewenangan tersebut bukan tanpa batas. Karena apabila kontrak dapat ditafsirkan secara bebas dan tanpa batas, maka kontrak tidak lagi memiliki kepastian hukum. Hukum kontrak sendiri didasarkan pada prinsip-prinsip yang menegaskan kekuatan mengikat kontrak. ${ }^{3}$ Hernoko dalam bukunya yang mengutip Ian Mecleod, telah memberikan contoh penerapan prinsip proporsionalitas ini dalam kasus Atlanta (1979), dimana hukum mengsyaratkan salah satu pihak memberikan jaminan untuk memastikan pelaksanaan kontrak.Ketika kontrak itu ternyata tidak dapat terlaksana, aturan hukum wajib denda, tanpa menghiraukan kegagalan itu bersifat major atau minor. Pengadilan memutuskan bahwa tidak adanya hubungan antara kegagalan prestasi pada satu sisi dengan jumlah denda pada sisi lain yang dianggap melanggar prinsip proporsional. Ratio decidendi putusan ini adalah pembebanan kewajiban (pembayaran denda) harus proporsional dengan kesalahannya. ${ }^{4}$

Pengaturan kontrak dalam praktik bisnis adalah untuk menjamin pertukaran kepentingan yang berupa hak dan kewajiban berlangsung secara proporsional bagi para pihak yang membuat kontrak, sehingga dengan demikian terjalin hubungan kontraktual yang adil dan saling menguntungkan. Bukan sebaliknya, merugikan salah satu pihak atau bahkan pada akhirnya justru merugikan para pihak yang berkontrak. Oleh karena itu, dengan adanya problematika diatas tentunya merupakan tantangan bagi para hakim yang mengadili sengketa kontrak, untuk memberikan jalan keluar terbaik demi terwujudnya kontrak yang saling menguntungkan bagi para pihak. Di satu sisi memberikan kepastian hukum dan di sisi lain memberikan keadilan. Meskipun sangat disadari untuk memadukan kepastian hukum dan keadilan menjadi perbuatan yang mustahil, namun melalui instrument kontrak yang mampu mengakomodasi perbedaan kepentingan secara 
proporsional, maka dilema pertentangan antara kepastian hukum dan keadilan tersebut akan dapat dieliminasi.

${ }^{3}$ Arthur S. Hartkamp, Marianne M.M. Tillema and Annemarie E.B. ter Heide, Contract Law in the Netherlands, Kluwer Law International, Alphen aan den Rijn, 2011, h. 34

4 Agus Yudha Hernoko, Hukum Perjanjian, Asas Proporsinalitas Dalam Kontrak Komersial, Cetakan Keempat, Kencana Prenadamedia Group, Jakarta, 2014,h. 30. 
Oleh karena itu amatlah penting bagi seorang hakim yang memutuskan sengketa kontrak komersial untuk memiliki pengetahuan terhadap asas utama dari pembentukan kontrak dalam mewujudkan pemenuhan hak dan kewajiban bagi para pihak dalam suatu hubungan kontraktual. Pentingnya asas proporsionalitas tersebut sejakan dengan cita hukum dari pembentukan kontrak itu sendiri yang dilandasi oleh adanya keadilan dan equity, yang mana menurut Aristoteles equity didefinisikan sebagai "koreksi terhadap hukum apabila hukum itu kurang tepat karena bersifat umum. Pandangan Aristoteles ini selanjutnya diadopsi oleh Thomas Aquinas dan dikembangkan lebih jauh pada abad pertengahan. Thomas Aquinas menyatakan bahwa secara ideal, hukum terpancar dari kekuasaan untuk memerintah guna kebaikan bersama, dalam hal ini dapat dipahami disamping adanya fondasi utama asas proporsionalitas dalam suatu hubungan kontraktual juga hendaknya dibarengi dengan adanya asas freedom of contract dan pacta sunt servanda. Selanjutnya berdasarkan uraian dari latar belakang masalah tersebut maka dapat dihasilkan dua rumusan masalah yang antara lain adalah:

1. Pemahaman asas proporsionalitas dalam penyelesaian sengketa kontrak oleh hakim.

2. Penerapan asas proporsionalitas dalam penyelesaian sengketa kontrak oleh hakim.

\section{PEMAHAMAN PEMAKNAAN ASAS PROPORSIONALITAS BAGI HAKIM DALAM MENGADILI SENGKETA KONTRAK DI INDONESIA}

Pada hakikatnya kewenangan hakim mengadili sengketa kontrak adalah selaras dengan tujuan hukum kontrak, yaitu untuk mengayomi pihak-pihak yang bersengketa, dengan memberikan perlindungan terhadap kepentingan para pihak secara adil (fairness), dan memberikan kepastian hukum terhadap kontrak yang disengketakan. Hal ini sejalan dengan apa yang telah dikemukakan oleh Gilbert Guillaume yang berpendapat bahwa the primary function of the judge is to adjudicate disputes. ${ }^{5}$ Dalam hal ini dapat dipahami pula bahwa Hakim berfungsi untuk mengadili dan memutus siapa yang benar dan siapa yang tidak benar, sehingga dalam hal ini hakim mempunyai kewenangan untuk menentukan hukum bagi sesuatu persoalan hukum konkrit yang dihadapkan kepadanya, untuk kemudian dilekatkan akibat hukumnya.

${ }^{5}$ Gilbert Guillaume, The Use of Precedent by International Judges and Arbitrators, Journal of International Dispute Settlement, Vol 2, No. 1, Oxford University Press, 2011, h. 6 
Oleh karena itu dalam menjalankan tugas judisialnya, hakim tidak boleh memihak kepada siapa pun juga kecuali hanya

kepada kebenaran dan keadilan, hal ini sebagaimana yang dikemukakan oleh Posner yang menyatakan bahwa "for the judge, the duty to decide the case and to do so, moreover, with reasonable dispatch is primary". 6

Proses penyelesaian sengketa yang dilaksanakan melalui pengadilan atau yang sering disebut dengan istilah "litigasi", yaitu suatu penyelesaian sengketa yang dilaksanakan dengan proses beracara di pengadilan di mana kewenangan untuk mengatur dan memutuskannya dilaksanakan oleh hakim. Litigasi merupakan proses penyelesaian sengketa di pengadilan, di mana semua pihak yang bersengketa saling berhadapan satu sama lain untuk mempertahankan hak-haknya di muka pengadilan. Hasil akhir dari suatu penyelesaian sengketa melalui litigasi idealnya adalah putusan yang menyatakan win-win solution. Adapun yang menjadi dasar kewenangan hakim dalam mengadili sengketa diatur dalam ketentuan Pasal 10 ayat (1) Undang-Undang Nomor 48 Tahun 2009 tentang Kekuasaan Kehakiman, dan Pasal 50 Undang-Undang Nomor 2 Tahun 1986 tentang Peradilan Umum, sebagaimana telah diubah terakhir dengan Undang-Undang Nomor 49 Tahun 2009 tentang Perubahan Kedua Atas Undang-Undang Nomor 2 Tahun 1986 tentang Peradilan Umum. Dalam Pasal 10 ayat (1) Undang-Undang Nomor 48 Tahun 2009 tentang Kekuasaan Kehakiman disebutkan bahwa "Pengadilan dilarang menolak untuk memeriksa, mengadili, dan memutus suatu perkara yang diajukan dengan dalih bahwa hukum tidak ada atau kurang jelas, melainkan wajib untuk memeriksa dan mengadilinya". Selanjutnya dalam Pasal 50 Undang-Undang Nomor 2 Tahun 1986 tentang Peradilan Umum, sebagaimana telah diubah terakhir dengan UndangUndang Nomor 49 Tahun 2009 tentang Perubahan Kedua Atas Undang-Undang Nomor 2 Tahun 1986 tentang Peradilan Umum, disebutkan bahwa "Hakim bertugas dan berwenang memeriksa, memutus dan menyelesaikan perkara". Bahkan secara filosofis, teoritik maupun dogmatik, hakim dapat secara aktif dalam menegakkan hukum dan keadilan melalui proses peradilan perdata. Sengketa kontrak adalah merupakan sengketa perdata oleh sebab itu hakim mempunyai kewenangan untuk mengadili sengketa kontrak. ${ }^{7}$

${ }^{6}$ Richard A. Posner, The Role of The Judge in The Twenty-First Century, Boston University Law Review, Vol. 86, 2006, h. 1053

7 Sunarto, Prinsip Hakim Bersifat Aktif Dalam Perkara Perdata, Disertasi, Program Doktor Ilmu Hukum Fakultas Hukum Universitas Airlangga, Surabaya, 2012, h. 353. 
Dalam memeriksa dan mengadili sengekta kontrak hakim sangat diharapkan menguasai asas proporsionalitas, adapun penerapan asas proporsionalitas ini menurut Harahap amatlah relevan mengingat dalam ilmu hukum tidak pernah ditemukan dan diperoleh serta menghasilkan pembuktian logis sebagaimana pasti dan logisnya pembuktian pada ilmu eksakta. Oleh sebeb itu dalam hal pembuktian penerapan asas proporsionalitas akan membantu hakim memberikan justifikasi mengenai putusan terhadap sengketa kontrak komersial tersebut, yang mana dalam hal ini asas proporsionalitas diberikan penekanan pada pembagian beban pembuktian secara adil bagi para pihak. ${ }^{8}$ Selanjutnya Atijah juga mengemukakan landasan pemikiran tentang asas proporsionalitas dalam kaitannya dengan peran kontrak seabgai landasan pertukaran yang adil di dalam dunia bisnis, yang mana pertemuan para pihak dalam mekanisme pasar harus sesuai dengan apa yang di inginkan (proportion what they want), adalah bentuk pertukaran yang adil (fair exchange) ${ }^{9}$

Ukuran proporsionalitas pertukaran hak dan kewajiban didasarkan pada nilainilai kesetaraan, kebebasan, distribusi-proporsinal, tentunya tidak dapat terlepas dari asas prinsip kecermatan, kelayakan, kepatutan. Untuk menemukan asas proporsionalitas dalam kontrak dengan menggunakan kriteria atau ukuran nilainilai tersebut, hendaknya tidak diartikan akan memperoleh hasil temuan serupa angka matematis. Asas proporsionalitas tidak mempermasalahkan keseimbangan atau kesamaan hasil secara matematis, namun lebih menekanka proporsi pembagian hak dan kewajiban diantara para pihak yang berlangsung secara layak dan patut. Keterpaduan asas-asas hukum kontrak, termasuk di dalamnya asas proporsionalitas dan keseimbangan merupakan pisau analisis untuk membedah eksistensi kontrak yang dibuat oleh para pihak.Tentunya sekarang bukan waktunya lagi untuk berkutat pada dilema ketidakseimbangan atau ketidakadilan dalam berkontrak, tetapi seyogianya lebih difokuskan pada bagaimana perbedaan kepentingan para pihak dapat diatur sedemikian rupa secara proporsional, disinilah peranan vital bagi hakim dalam suatu sengketa kontrak, yang mana apabila suatu kontrak berujung

\footnotetext{
${ }^{8}$ M. Yahya Harahap, Hukum Acara Perdata, Sinar Grafika, Jakarta, 2006 ,h.507.

${ }^{9}$ P.S. Atijah, An Introduction to the Law of Contract, Oxford University Press, h.5.
} 
pada sengketa para pihak kontraktual, pemenuhan hak dan kewajiban kontraktual masing-masing pihak, amat bergantung pada penilaian majelis hakim yang memeriksa perkara.

Asas proporsionalitas dalam kontrak dapat diartikan sebagai asas yang mendasari pertukaran hak dan kewajiban para pihak sesuai dengan proporsi atau bagian masing-masing pihak sesuai dengan hak dan kewajibannya. Proporsionalitas pembagian hak dan kewajiban ini di wujudkan dalam proses hubungann kontraktual yang dapat dimulai pada fase prakontraktual, pembentukan kontrak maupun pelaksanaan kontrak. Perlu digaris bawahi pula bahwa pada dasarnya asas proporsionalitas ini tidak mempersoalkan keseimbangan atau kesamaan antara hasil dari masing-masing pihak, namun lebih ditekankan pada proporsi pembagian hak dan kewajiban di antara para pihak. ${ }^{10}$ Menurut Hernoko, upaya untuk mencari makna asas proposrionalitas merupakan proses yang tidak mudah, bahkan ada kalanya terjadi peristiwa tumpeng tindih dengan pemahaman terhadap asas keseimbangan. Hal ini adalah sesuatu yang wajar mengingat antara proporsionalitas sendiri dengan keseimbangan merupakan dua asas yang keberadaannya tidak dapat dipisahkan dalam hukum kontrak, namun demikian tetap ada benang merah yang dapat ditarik dari dua asas tersebut, karena pada dasarnya antara proporsionalitas dan keseimbangan memang berbeda namun tampak serupa.

Hakim yang mengadili sengketa kontrak perlu memahami benang merah antara proporsionalitas dan keseimbangan tersebut, yang mana dalam hal ini pemikiran dan pemahaman terhadap asas proporsionalitas perlu dikemukakan disamping asas keseimbangan dalam kontrak. Hal ini bertujuan untuk membedakan keduanya, yang mana upaya ini dapat diawali dari makna leksikal dari dua istilah tersebut. Sedangkan yang kedua penelurusan makna dapat dilakukan dari makna substansi yang terkandung antara proporsionalitas dan keseimbangan, terhadap hal ini Hernoko telah mengemukakan bahwa: ${ }^{11}$

1. Makna leksikal ada beberapa konsep yang menyamakan antara proporsionalitas dan keeimbangan, dan sebaliknya ada pula yang

\footnotetext{
${ }^{10}$ Agus Yudha Hernoko, Op.Cit.,h.31-32.

${ }^{11}$ Ibid.,h.78-79.
} 
membedakan antara proporsionalitas dan keseimbangan, sekalipun belum tegas perbedaannya.

2. Keseimbangan sering pula diartikan sebagai kesamaan, sebanding dalam jumlah, ukuran atau posisi. Perlu dilakukan penegasan di sini bahwa dalam perspektif kontrak asas keseimbangan yang ada adalah penekanan pada posisi tawar menawar para pihak (bargaining position) yang harus seimbang. Oleh sebab itu ketiadaan keseimbangan posisi tawar menawar para pihak akan mengakibatkan kontrak menjadi tidak seimbang dan membuka peluang intervensi penguasa (yang dalam hal ini adalah hakim yang mengadili sengketa kontrak), untuk menyeimbangkan posisi para pihak dalam suatu hubungan kontraktual.

3. Asas proporsionalitas seringkali dipahami dalam konteks hukum pembuktian, meskipun pada dasarnya kedudukan asas proporsionalitas tidak saja berada dalam ranah pembuktian saja, namun dalam suatu hubungan kontraktual asas proporsionalitas harus dimaknai sebagai pembagian hak dan kewajiban menurut proporsi yang meliputi segenap aspek kontraktual secara keseluruhan, atau dengan kata lain asas proporsionalitas harus dipahami sebagai fondasi pembentukan kontrak yang baik, sehingga dengan pengabaian asas proporsionalitas, maka suatu kontrak berpotensi menjadi sengketa, yang mana dalam hal ini ketika hakim mengadili suatu sengketa kontrak maka pencarian elemen proporsionalitas dalam suatu pembuktian haruslah berdasarkan pada pencarian fondasi pembentukan kontrak tersebut yang idealnya mengandung elemen-elemen proporsionalitas.

Selain metode pemahaman leksikal dan substansi dari proporsionalitas tersebut, hakim yang mengadili sengketa kontrak juga dapat menggunakan metode interpretasi, ini adalah suatu metode untuk mencari atau menemukan makna yang hakiki, dari suatu ketentuan, peraturan, pernyataan dan lain-lain, dengan kata lain suatu interpretasi yang jelas akan berfungsi sebagai rekonstruksi cita hukum yang tersembunyi. Dalam hal intepretasi kontrak dapat dipahami sebagai suatu proses dimana seseorang (yang dalam hal ini adalah hakim yang mengadili sengketa kontrak), memberikan makna terhadap suatu symbol dari ekspresi yang digunakan oleh orang lain yang dituangkan dalam suatu perbuatan oral, tulisan maupun 
perbuatan, yang menjadi media dituangkannya suatu kontrak. Oleh sebab itu pemahaman komprehnsif terhadap substansi kontrak amat tergantung pada kemampuan dan penguasaan metode-metode interpretasi yang harus dimiliki oleh hakim yang mengadili sengketa kontrak. Yang mana hakim yang mengadili sengketa kontrak setidak-tidaknya harus memahami beberapa metode interpretasi seperti gramatikal, teleologis, sosiologis, autentik, sistematis, historis, restriktif, ekstensif, analog dan a-contrario. ${ }^{12}$ Interpretasi kontrak adalah metode pemungkas yang digunakan oleh hakim dalam memahami proporsionalitas dalam suatu kontrak, yang mana tentu saja penggunaan metode interpretasi ini adalah upaya setelah menggunakan metode penilaian leksikal dan substansi. Interpretasi jangan sampai dijadikan metode pertama yang di gunakan, hal in dikarenakan apabila interpretasi dilakukan tanpa adanya penelusuran leksikal dan substansi maka akan berujung pada kesalahan interpretasi yang dapat berakibat fatal pada suatu fase kesesatan berpikir, yang mana secara otomatis akan menimbulkan persoalan baru yang dapat berujung pada integritas hakim dalam mengadili perkara.

Pada akhirnya dapat dipahami bahwa inti dari asas proporsionalitas adalah suatu perwujudan doktrin "keadilan berkontrak" yang mengoreksi dominasi asas kebebasan berkontrak yang dalam beberapa hal justru menimbulkan ketidakadilan.Perwujudan keadilan berkontrak ditentukan melalui dua pendekatan.Pertama, pendekatan prosedural, pendekatan ini menitikberatkan pada persoalan kebebasan kehendak dalam suatu kontrak. Pendekatan kedua, yaitu pendekatan substansif yang menekan kandungan atau substansi serta pelaksanaan kontrak. Dalam pendekatan substansif perlu diperhatikan adanya kepentingan yang berbeda . Atas pemaparan hal diatas, dapat dimaknai mengenai asas proporsionalitas yang bermakna sebagai asas yang melandasi atau mendasari pertukaran hak dan kewajiban para pihak sesuai proporsi atau bagiannya dalam seluruh proses kontraktual yang tidak mempersoalkan masalah keseimbangan (kesamaan) hasil secara matematis,namun lebih menekankan pada proporsi pembagian hak dan kewajiban di antara para pihak yang berlangsung secara layak dan patut (fair and reasonable).

Adapun mengenai ruang lingkup dan daya kerja asas proporsionalitas tampak lebih dominan pada kontrak, dengan asumsi dasar bahwa karakteristik kontrak telah menjadikan posisi para pihak dalam suatu hubungan kontraktual berada pada fase

\footnotetext{
${ }^{12}$ Ibid.,h. 223-235.
} 
kesetaraan, sehingga tujuan para kontrakan yang berorientasi pada keuntungan bisnis akan terwujud apabila terdapat pertukaran hak dan kewajiban yang proporsional. Yang mana perlu ditegaskan kembali bahwa asas proporsionalitas tidak dilihat dari konteks keseimbangan-matematis (equilibrium), tetapi pada proses dan mekanisme pertukaran hak dan kewajiban yang berlangsung secara adil dan pemahaman inilah yang seharusnya dimiliki oleh para hakim yang mengadili setiap sengketa kontrak.

\section{KESIMPULAN}

Penelusuran makna sesungguhnya dari suatu kontrak melalui asas proporsionalitas, merupakan jawaban dari pertanyaan mengenai asas utama yang harus dijadikan pedoman bagi hakim dalam menyelesaian sengketa kontrak, disamping asas-asas kontraktual lainnya. Hal ini tidaklah gampang, karena pemahaman terhadap asas proporsionalitas tidak sekedar hanya membaca memahami dan menafsirkan saja, lebih dari itu pemahaman terhadap kriteria proporsionalitas tersebut juga harus diperoleh melalui suatu pengalaman, aktifitas dan transfer knowledge dari para punggawa hukum kontrak. Karena proporsionalitas tadi bukan berwujud suatu proporsi matematis yang mana satu tambah satu selalu menghasilkan dua, namun mempunyai substansi pemenuhan hak dan kewajiban yang dapat dikatakan tidak abstrak, namun nyata, tidak bersifat pasti namun memberikan kepastian. Dalam hal ini setiap sengekta kontrak yang dibawa ke ranah pengadilan pasti diharapkan akan memberikan kepastian hukum bagi para pencari keadilan, oleh sebab itulah hakim dalam memutus suatu sengketa kontrak komersial harus benar-benar memahami asas proporsionalitas ini sebelum memahami asas-asas kontraktual lainnya.

Memang di dalam faktanya tidak banyak hakim yang memahami penerapan asas proporsionalitas ini, hal ini dikarenakan bukan ketidak mampuan akademis ataupun ketidak mampuan untuk memahami, namun lebih dari itu disebabkan karena suatu paradigma pemahaman asas proporsionalitas yang disamakan dengan asas-asas kontraktual yang lain, mengaplikasikan asas proporsionalitas hanya melalui langkah-langkah membaca memahami dan menafsirkan saja. Sehingga 
putusan terhadap sengketa kontrak komersial berpotensi akan menimbulkan multi tafsir maupun ambiguitas keinginan para pihak dalam suatu hubungan kontaktual, yang pasti hal ini akan membawa suatu kondisi jauh dari apa yang dinamakan dengan win-win solution. Oleh sebab itu kemampuan untuk memahami dan mengaplikasikan asas proporsionalitas merupakan hal mutlak yang harus dikuasai oleh hakim yang menangani sengketa kontrak komersial, karena tanpa adanya dua hal tersebut (kemampuan untuk memahami dan mengaplikasikan asas proporsionalitas), dapat dipastikan tidak akan pernah tercipta suatu penyelesaian sengketa kontrak komersial yang akan meciptakan efisiensi dan iklim usaha yang kondusif, sekaligus bernuansa win-win solution. 
Bibliografi

Agus Yudha Hernoko, Hukum Perjanjian, Asas Proporsinalitas Dalam Kontrak Komersial, Cetakan Keempat, Kencana Prenadamedia Group, Jakarta, 2014.

M. Yahya Harahap, Hukum Acara Perdata, Sinar Grafika, Jakarta, 2006.

Arthur S. Hartkamp, Marianne M.M. Tillema and Annemarie E.B. ter Heide, Contract Law in the Netherlands, Kluwer Law International, Alphen aan den Rijn, 2011.

Gilbert Guillaume, The Use of Precedent by International Judges and Arbitrators, Journal of International Dispute Settlement, Vol 2, No. 1, Oxford University Press, 2011.

P.S. Atijah, An Introduction to the Law of Contract, Oxford University Press.

Sunarto, Prinsip Hakim Bersifat Aktif Dalam Perkara Perdata, Disertasi, Program Doktor Ilmu Hukum Fakultas Hukum Universitas Airlangga, Surabaya, 2012.

Richard A. Posner, The Role of The Judge in The Twenty-First Century, Boston University Law Review, Vol. 86, 2006. 